Southern Methodist University

SMU Scholar

\title{
Kirsten Swinth. Feminism's Forgotten Fight: The Unfinished Struggle for Work and Family
}

\author{
Joanna L. Grossman \\ Southern Methodist University, Dedman School of Law
}

\section{Recommended Citation}

Joanna L. Grossman, KIRSTEN SWINTH. Feminism's Forgotten Fight: The Unfinished Struggle for Work and Family, 125 Am. Hist. Rev. 979 (2020) (reviewing KIRSTEN SWINTH, FEMINISM'S FORGOTTEN FIGHT: THE UNFINISHED STRUGGLE FOR WORK AND FAMILY (2018)).

This document is brought to you for free and open access by the Faculty Scholarship at SMU Scholar. It has been accepted for inclusion in Faculty Journal Articles and Book Chapters by an authorized administrator of SMU Scholar. For more information, please visit http://digitalrepository.smu.edu. 
diverse origins that influenced existentialist thought in the Arab world, the main emphasis is placed on Sartre to the exclusion of other potential influences, not least of all the Christian existentialism of Søren Kierkegaard, who is mentioned only in passing. This raises a question: To what extent is No Exit about Arab existentialism, and to what extent is it a story of the Arab world's relationship with Sartre? Even this question might have been explored in greater depth, since Di-Capua confines his study to the Eastern Mediterranean and Middle East. The fact that Francophone elites in Algiers and Tunis were engaged in French intellectual debates and could access works without the need for translation hints at a more diverse picture than the one presented in No Exit. More broadly, throughout much of the book, the politics of the Middle East are occasionally presented in vague terms, with the significance of major events such as the Bandung Conference or the Algerian War left largely unexplained. Readers who are unfamiliar with the general political developments of Africa and the Middle East between 1945 and 1967 might find themselves in need of further historical context.

Yet what Di-Capua's book captures quite well is the sense of optimism and revolutionary potential that inspired an entire generation of Arab intellectuals in the two decades following the Second World War. No Exit is certainly not stodgy intellectual history. It is concerned with placing ideas in historical context, and for this reason No Exit will prove valuable for historians of the modern Middle East as well as scholars working in the field of global intellectual history.

Gavin MurRay-MiLLER Cardiff University

\section{KiRsten Swinth. Feminism's Forgotten Fight: The Unfin- ished Struggle for Work and Family. Cambridge, Mass.: Har- vard University Press, 2018. Pp. 339. Cloth \$35.00.}

Why did feminists ever think women could have it all? Well, they didn't exactly. They did not believe that women could "heroically be everything to everyone." What they thought was that society could be restructured so that the family could be more egalitarian, men could share meaningfully in the raising of children, the state could support families through the provision of high-quality childcare, and the workplace could be open on equal terms to women. What they wanted was to redefine what it meant to "have it all" - and to stop the gender-specific "fetishizing" of the concept that purported to allow women to juggle an impossible number of roles (1-2). What they got instead was marginally improved access to employment opportunities, along with the right to continue doing the lion's share of care work with even less support from the government than before. And we tend to blame the feminists themselves for the impossible balancing that defines many women's lives today. In Feminism's Forgotten Fight: The Unfinished Struggle for Work and Family, Kirsten Swinth corrects the record.

The problem is not that feminists didn't have a meaningful vision - or that their vision was misdirected. Women changed, but society did not. Opponents of equality obfuscated, resisted, and vetoed the structural changes that might have permitted women to be equal participants in all aspects of civil society. These obstructionist efforts were so successful that not only did opponents manage more or less to preserve traditional gender roles in the home; they also erased our memory of feminists' broader vision. Second-wave feminists met resistance with pragmatism, which led them to adapt old strategies to fit new circumstances and, as needed, to water down their utopian vision. History, Swinth convincingly argues, has simply forgotten that second-wave feminists, across a fifteen-year burst of activism from 1963 to 1978, once had a "breathtaking vision of comprehensive change that they believed would produce better lives for women, men, and children in a more egalitarian society" (3).

Swinth uses archival records to reconstruct the role of individuals and institutions that were important to second-wave feminism - and to tell a comprehensive story of the movement and its mission to dismantle the breadwinner/homemaker ideal that defined so much of society. The National Organization for Women plays a starring role, along with activists like Letty Pogrebin, Betty Friedan, Pauli Murray, Bella Abzug, and Ruth Bader Ginsburg. Swinth begins where the movement began, with efforts by first women and then men to redefine the "self." Women were not just mothers and wives; they were fully formed humans with aspirations and potential, and both women and society suffered when women were relegated solely to the domestic sphere. As a song written by Betty Friedan in 1970 goes, "We're breaking out of our cage of ruffles and rage... We're more than mothers and wives with secondhand lives" (quoted on 25). Those lyrics capture the heart of the second-wave feminist movement, as well as the diversity of methods used to transform women's beliefs about themselves. From consciousness-raising groups to singalongs to mimeographed manifestos, movement leaders understood that women had to aspire to more before society might allow them to achieve it. Feminist social scientists aided the effort by proving that "the root cause of male/female differences in career success lay not in in- 
born sex-differentiated traits but in gendered socialization" (35). This vision of woman as a "whole human self" led to an influx of women into the wage economy, and a desire to rethink the role of men as well (15). Swinth takes up fatherhood in chapter 2. "Let's share childcare" was a popular slogan in a short-lived and ultimately unsuccessful movement in the early 1970s. Like women who sought to reclaim their whole-human status, men sought to round themselves out with greater commitment to children and to soften themselves by transforming ideals of masculinity. Though few in number, these men were an "important component of secondwave feminist activism," which focused on making men "part of the solution rather than part of the problem" (45). The men, for their part, participated in some consciousness-raising activities just like their feminist counterparts-holding hands and following enforced rules of "alternative masculinity" — but they also focused outwardly on breaking down sex-role stereotypes in society and exposing the degree to which living up to the male provider role forced men to be exploited by a "dehumanizing capitalist system" (51).

The first two chapters are the perfect setup for the third, which examines the now-woke individuals and organizations committed to dismantling the breadwinner/homemaker dichotomy - a natural consequence of the emerging ideas about womanhood and manhood. Feminists of the era firmly believed that "the gendered assignment of breadwinning and homemaking handcuffed both sexes" (75). Activists, writers, social scientists, and lawyers took on the patriarchal family, fighting for legal and social transformation. With the help of architect-of-equality Ruth Bader Ginsburg, legal inroads turned out to be easier to pave than social ones. Chapter 4 revisits the nation's struggle over housework and who should do it. This was a multifaceted fight, in which women enlisted many strategies. What better way to send a message to patriarchal men than by waging a housework strike? Betty Friedan organized the Strike for Equality Day, urging adoption of the term "housespouse" and, more substantively, an end to women's unpaid servitude in the home by distributing work more fairly or accounting for its economic value (99). Through this activism, "second-wavers showed how the idealization of housework as an expression of a woman's devotion to her family had generated a lowstatus and racialized workforce, both paid and unpaid, that blocked women's equality" (132). Or, as Marlo Thomas captured the idea in one of the songs on the album called Free to Be . . You and Me, "when there's housework to be done, let's do it together." This chapter is important to Swinth's overall project of revisiting a history that has often cast feminists as hostile to housewives, when, in fact, they fought hard to improve the treatment not just for those women but also for domestic workers.

The remaining four chapters explore the fights over "care work," childcare, maternity, and flex time. Each of these chapters tells the story of the role the issue played in the movement, the people responsible for pushing the second-wave agenda, the strategies for reform, as well as the successes and failures. With each, activists sought to achieve changes in social norms, legal rules, and government policies that would permit women and their families to thrive. Swinth excavates long-forgotten-but great-ideas that would have made this more possible, including universal day care and universal basic income. These activists understood all too well that women's equality and economic security would turn on "a new system of shared private and public action to meet the basic needs of American families" (154). Through these struggles, they grappled with how to "frame a claim for women's autonomy, choices, and full participation in society without conveying disregard for children." This, Swinth writes, was a "thorny dilemma" (163).

All told, Swinth is persuasive in recounting the bold vision of second-wave feminists, which "changed how Americans think and act so dramatically that we can almost no longer conceive how profoundly the movement transformed our society." The straits we find ourselves in today come not from a failure of our foremothers' imagination, but from the force with which "feminism's opponents clawed back" (252-253).

Almost forty years later, women struggle with the same juggling act. A March 2019 study in Forbes magazine reported that "women are more stressed than men, many of them managing both the family and work. They do not feel supported enough by their employers, only half of whom offer any workplace wellness program[s]" (Louise Chunn, "Women Are at a Breaking Point Because of Workplace Stress," Forbes, March 26, 2019). Numerous studies have shown that women continue to do disproportionate housework and childcare even when working the same number of hours as a spouse or partner. In some ways, the balancing act is even more treacherous, as aging parents are living longer and becoming dependent on their adult children-usually daughters - to care for them. The sandwich generation not only cares for children and the elderly, but also works in an age when technology obliterates any boundary between work and family life that may once have been discernible.

Yet many modern-day feminists continue to call for women to be better at accomplishing the impossible. Sheryl Sandberg urged women to "lean in" to work as a means of overcoming seemingly intractable obstacles to equal advancement. Anne-Marie Slaughter chided women for being foolish enough to believe that women could "have it all." But neither they nor many other commentators call for the restructuring of both work and family that those second-wavers envisioned - and which is an obvious prerequisite to women's equality. "Feminists," Swinth makes the case, "are not to blame 
for today's superwoman dilemma." They "imagined remaking society from the bottom up and from the inside out," but were left only, impossibly, to remake themselves in a society that allowed them crumbs of equality only as long as the cake was left intact (2).

While second-wave feminists did not succeed in remaking society from top to bottom, they did effect significant change. The Equal Pay Act of 1963 requires that employers pay men and women equally for equal work. Title VII of the Civil Rights Act of 1964 prohibits employers from making employment decisions based on sex, from engaging in sex stereotyping, and from adopting neutral rules that disproportionately disadvantage women. The Pregnancy Discrimination Act of 1978 prohibits employers from discriminating against women on the basis of "pregnancy, childbirth, or related medical conditions." The Family and Medical Leave Act of 1993 requires employers of a certain size to give employees unpaid leave when necessary to care for newborn or newly adopted children, or to tend to their own serious health conditions. In addition, the Equal Protection Clause of the U.S. Constitution's Fourteenth Amendment has been interpreted to forbid sex-based classifications by public employers in most circumstances. Moreover, state legislatures have passed a set of antidiscrimination laws that are often even more protective of women's rights than federal law is, requiring employers to accommodate pregnancy-related disability or funding paid parental leave through state disability insurance or applying general anti-discrimination norms to even smaller employers. These protections against discrimination and stereotyping are a necessary, though not sufficient, condition of equality.

Anti-discrimination laws were central to opening doors of the American workplace to women and to eradicating some of the most common and overt forms of sex discrimination that consigned women to traditional female (and lower-paying) jobs or excluded them from work altogether. But once women cross these thresholds, they still encounter highly gendered terrain. They are paid less, promoted less often, presumed incompetent, harassed or assaulted more, and punished in myriad ways for being pregnant or becoming mothers. Yet they persist, now accounting for more than half of the U.S. labor force. But an equal head count is not the same as an equal workforce or an equal society.

The conundrum for women today is how to survive and thrive in a society that has been stubbornly resistant to egalitarian ideals and in which government support for families is scarce and diminishing for families. The U.S. ranks comparatively low on measures of gender equality, in no small part because of the limited access to paid parental leave. But that's just the tip of the iceberg. Women are disproportionately poor and more likely to be raising children alone. New calls for state support of families coming from Martha Fineman and Maxine Eichner, among others, merit serious consideration.

Swinth does more than provide a history lesson on second-wave feminism. Through her painstaking retelling of a complicated movement, she exhumes a blueprint that could be put to good use today. As she begins the book, "It's not that feminism failed American women, but that society failed to deliver on the promise of fairness for which feminists fought" (12). The failure is part of history, but the promise could be the future. But urging women to squeeze additional hours out of already exhausting days, while workplaces, marriages, families, and political institutions remain frozen in time, will not get us there. For them to "have it all," we must change it all.

JoANNA L. GRossman Southern Methodist University

Jenny Andersson. The Future of the World: Futurology, Futurists, and the Struggle for the Post-Cold War Imagination. New York: Oxford University Press, 2018. Pp. xi, 267. Cloth \$78.00.

In a trend that is fairly recent, the future has become a central issue in the humanities and has been particularly taken up in the historical sciences. Of course, historical scholarship has always drawn on the category of time, since periodization is one of its key tasks, and from the 1990s historians have been strongly influenced by studies on cultural memory that stress that the past is constantly present in everyday experience (e.g., Jan Assmann, Das kulturelle Gedächtnis: Schrift, Erinnerung und politische Identität in frühen Hochkulturen [1992]; Pierre Nora, ed., Les lieux de mémoire [1997]). However, it is only in the last few years that historical scholarship has occupied itself more fully both with processes of reconfiguring the past, the present, and the future and with the specific role futures have played in history. This is a change of approach, which can plausibly be seen as a reaction to increasingly persistent crisis perceptions (e.g., "AHR Forum: Histories of the Future," AHR 117, no. 5 [2012]; Chris Lorenz and Berber Bevernage, eds., Breaking Up Time: Negotiating the Borders between Present, Past and Future [2013]; Elke Seefried, ed., "Politics and Time from the 1960s to the 1980s," special issue, Journal of Modern European History 13, no. 3 [2015]; Seefried, Zukünfte: Auf- 